\title{
Strophatrypa, a new genus of Brachiopoda (Atrypidae), from upper Silurian strata of the Alexander terrane, Southeast Alaska
}

\author{
ARTHUR J. BOUCOT, ROBERT B. BLODGETT \& DAVID M. ROHR
}

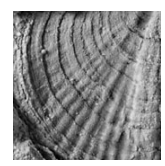

\begin{abstract}
The atrypid brachiopod Strophatrypa skaflestadi gen. et sp. nov. occurs in unnamed upper Silurian strata exposed near the town of Hoonah on northeast Chichagof Island, Southeast Alaska. The new genus represents the first strophic atrypoid with many characters otherwise similar to those of the Atrypidae. Although this genus is known from only a single bed at one Alaskan locality, its unique morphology is worth noting in anticipation that similar forms may be discovered elsewhere in the Alexander terrane, or especially somewhere in Siberia where other taxa restricted to the Silurian of the Alexander terrane are shared. This paper represents a further contribution to our limited knowledge of the Silurian brachiopods of the Alexander terrane of Southeast Alaska. $\bullet$ Key words: Brachiopoda, late Silurian, new genus, Alexander terrane, Southeast Alaska, U.S.A., palaeoecology, slope facies, palaeogeography.
\end{abstract}

Boucot, A.J., BLODGETT, R.B. \& RoHR, D.M. 2012. Strophatrypa, a new genus of Brachiopoda (Atrypidae), from upper Silurian strata of the Alexander terrane, Southeast Alaska. Bulletin of Geosciences 87(2), 261-267 (4 figures). Czech Geological Survey, Prague, ISSN 1214-1119. Manuscript received June 14, 2011; accepted in revised form December 21, 2011; published online March 14, 2012; issued March 30, 2012.

Arthur J. Boucot, Department of Zoology, Oregon State University, Corvallis, Oregon 97331, U.S.A.; boucota@science.oregonstate.edu • Robert B. Blodgett, Consulting Geologist, 2821, Kingfisher Drive, Anchorage, Alaska 99502, U.S.A.; robertbblodgett@yahoo.com • David M. Rohr, Department of Earth and Physical Sciences, Sul Ross State University, Alpine, Texas 79832,U.S.A.; drohr@sulross.edu

The present paper describes a new brachiopod genus and species, Strophatrypa skaflestadi, found in an unnamed Silurian unit of mixed siliciclastics and limestones exposed in and around the town of Hoonah, situated on the northeast part of Chichagof Island. It was discovered and collected by R.B. Blodgett, D.M. Rohr, and J. E. Skaflestad on July 30, 2010 in the north side of a small quarry (Fig. 1) about $1 \mathrm{~km}$ east of Hoonah Airport runway on Chichagof Island, south-eastern Alaska, U.S.A. (locality 10RB10 - Latitude $58^{\circ} 05.716^{\prime} \mathrm{N}$, Longitude $\left.135^{\circ} 23.152^{\prime} \mathrm{W}\right)$. The quarry is reached by a small short road leading from the west from Forest Service Road 8052, the main road leaving and heading south of the town of Hoonah. The quarry is situated in the NW1/4 of the SE1/4 of section 35, T. 43 S., R. 62 E., Juneau A-5 1:63,360 scale quadrangle (Map edition 1994). The source quarry exposes two separate stratigraphic intervals: a lower greenish-gray, medium-bedded siltstone interval which forms the base of the quarry, and an upper limestone interval which forms cliffs on the south and west side of the quarry. The fossil-rich part (field locality 10RB10) of the siltstone beds is exposed on the north side of quarry (near NE end of quarry). The siltstone beds near the fossil locality strike N-S and dip steeply $70-75^{\circ}$ to the west. This rich shelly fauna consists primarily of brachiopods along with a lesser amount of gastropods and bivalves (see Kříž et al. 2011 for description of the bivalves from this horizon). The fossiliferous zone which yielded this fauna was the only easily visible fossil-rich part of the siltstone beds exposed in the quarry. The age of this fossil horizon was indicated to be late Wenlock or early Ludlow according to the associated bivalve fauna (Kř́ž et al. 2011). The brachiopod fauna found here indicates only a generalized late Silurian age, and occurs primarily as disarticulated external and internal moulds extracted from siltstones. A limestone sample collected by D.M. Rohr in 2010 from the overlying limestone interval in the quarry was submitted to Ladislav Slavík (Praha, Czech Republic) who acidized the sample to extract conodonts. Unfortunately the sample proved to be barren. A sample of siltstone from the brachiopod-rich horizon was also unsuccessfully examined for chitinozoans by Viiu Nestor (Tallinn, Estonia).

This paper represents a further contribution to our limited knowledge of the Silurian brachiopods of the Alexander terrane of Southeast Alaska. Previous works dealing with Silurian brachiopods of this terrane include Kirk 

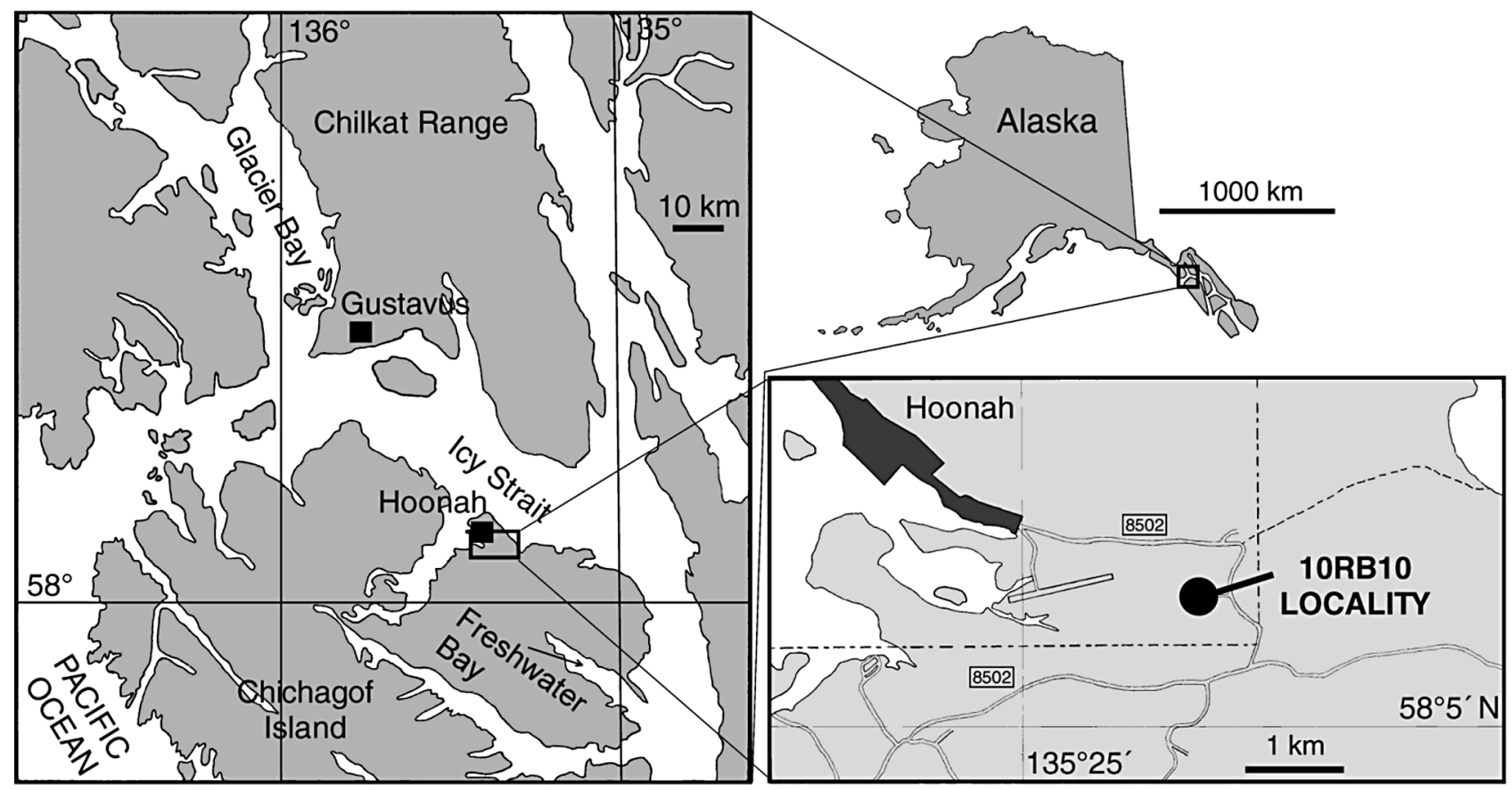

Figure 1. Location of the field locality 10RB10, East of Hoonah Airport, Latitude $58^{\circ} 05.716^{\prime}$ N, Longitude $135^{\circ} 23.152^{\prime}$ W, Chichagof Island, Southeast Alaska, U.S.A. (from Kř́̌ž et al. 2011).

(1922, 1925, 1926), Kirk \& Amsden (1952), and Savage (1989) on faunas found to the south on the western side of Prince of Wales Island and its westerly adjoining smaller islands. These faunas are from shallow-water platform carbonate facies rocks and are richly endowed with large pentameroid brachiopods [i.e., Kirkidium, Brooksina, Harpidium, and Cymbidium]. The Chichagof Island brachiopod fauna represents a deeper-water, upper slope facies with a somewhat differing fauna, notably lacking in large pentameroids.

\section{Geological setting}

Palaeozoic rocks are exposed throughout much of the northeast part of Chicagof Island of Southeast Alaska, however, little is known of its Palaeozoic fauna and flora. The only publications providing formal descriptions of Palaeozoic fossils are two papers on Silurian bivalves. Kirk (1927a) who described and illustrated Pycinodesma benjamini (Kirk), under the genus name Pycnodesma, which he later changed (Kirk 1927b) to Pycinodesma upon learning that the genus name was pre-occupied. This particular species was found in exposures of the type section of the Kennel Creek Limestone on the southern side of Freshwater Bay (Fig. 1). The other paper, Kř́ž et al. (2011), described a new bivalve community (Goniophora thula-Mytilarca boucoti Community) composed of 9 species from the same locality as Strophatrypa.
Geologic maps covering all or parts of Chichagof Island include Lathram et al. (1958), Lathram et al. (1959), Loney et al. (1963a), Loney et al. (1963b) and Karl (1999). Much of the basic stratigraphic nomenclature for this part of the island was established by Loney et al. (1963b). On the geologic map of northeast Chichagof Island of Karl (1999), the area including the quarry from which this collection was made was shown as being part of the Devonian age Cedar Cove Formation. Our field study indicated that many of the rocks exposed in the immediate area of Hoonah do not belong to the Cedar Cove Formation as indicated on the map of Karl (1999), but rather belong to a new unnamed mixed siliciclastic/limestone lithostratigraphic unit bearing late Silurian age fauna, probably forming a shelf-to-basin transitional lithofacies which lay to the north of late Silurian carbonate platform rocks of the Kennel Creek Limestone (Rohr et al. 2011). The Kennel Creek Limestone was established by Loney et al. (1963b), who considered it to be Middle Devonian in age. The only significant fossils found in the latter unit are the bivalve Pycinodesma and amphiporid stromatoporoids. More recent studies in Southeast Alaska clearly indicate that Pycinodesma is of late Silurian age, as originally indicated by Kirk (1927a, b), and the Kennel Creek is now recognized to be late Silurian in age.

Carbonate platform facies of the Kennel Creek Limestone, as mentioned above, are well exposed to the south of Hoonah, most notably in and around Freshwater Bay. One of the nearest Kennel Creek quarry exposures to our 
bivalve locality contained cyanobacterial reefal mound buildups, similar to those found in coeval platform edge rocks exposed throughout much of the Alexander terrane (Fig. 2) of Southeast Alaska and the Farewell terrane of southwestern Alaska (Clough \& Blodgett 1988, Rigby et al. 1994), as well as in the Urals.

Palaeozoic strata of northeast Chichagof Island belong to the Alexander terrane (Fig. 2), a major tectonic element in Southeast Alaska, northwestern British Columbia, and southwestern Yukon Territory. This terrane along with many other terranes forms an accretionary complex of allochthonous terranes which characterize much of the Western Cordillera of North America. The Alexander terrane was one of first terranes to be recognized in western North America (Berg et al. 1972, Jones et al. 1972). Recent palaeobiogeographic studies indicate that the Alexander terrane has a fauna most similar to Siberia (Blodgett et al. 2002, 2003, 2010; Pedder 2006), notably its eastern portion. This terrane most likely originated as a rifted block of the eastern Siberian palaeocontinent, probably breaking away in the latter part of the Devonian (Blodgett et al. 2010).

Silurian shelly faunas of the Alexander terrane are distinctly different from those found along the western margin of cratonic North America. These differences are especially borne out by the gastropods (Rohr \& Blodgett 2003, 2008; Rohr et al. 2003, 2008), brachiopods (Blodgett \& Boucot 2009; Blodgett et al. 2002, 2010) and calcareous sponges (Rigby et al. 1994) found in Silurian strata of Alexander terrane. Summary data on the palaeobiogeographic affinities of the major Siluro-Devonian megafossil groups found in the Alexander terrane can be found in Blodgett et al. (2010). This latter study clearly shows the strongest palaeobiogeographic affinities are consistently found to be with the Siberian palaeocontinent. On-going studies of the Silurian brachiopods (by A.J. Boucot \& R.B. Blodgett) and bivalves (by J. Kříž) will presumably throw additional light on this issue.

The fossil horizon containing Strophatrypa skaflestadi gen. et sp. nov. is a tan-weathering, greenish-gray, medium-bedded calcareous siltstone. Fine-sand to silt-sized grains of angular quartz, plagioclase and chert, minor detrital mica and glauconite are present. The fauna of this locality consists of a rich shelly benthos, especially brachiopods, but secondarily followed by bivalves and gastropods. Cephalopods are rare, favositid tabulate corals are also present, but form only a very minor component. Brachiopods retain shell microstructure, and they show little evidence of micritized rims indicating deposition below the photic zone (Flügel 2004). The brachiopods from this horizon were for the most part disarticulated, with the exception of a minority of the isorthids and Strophatrypa skaflestadi gen. et sp. nov. which remain articulated. The high degree of

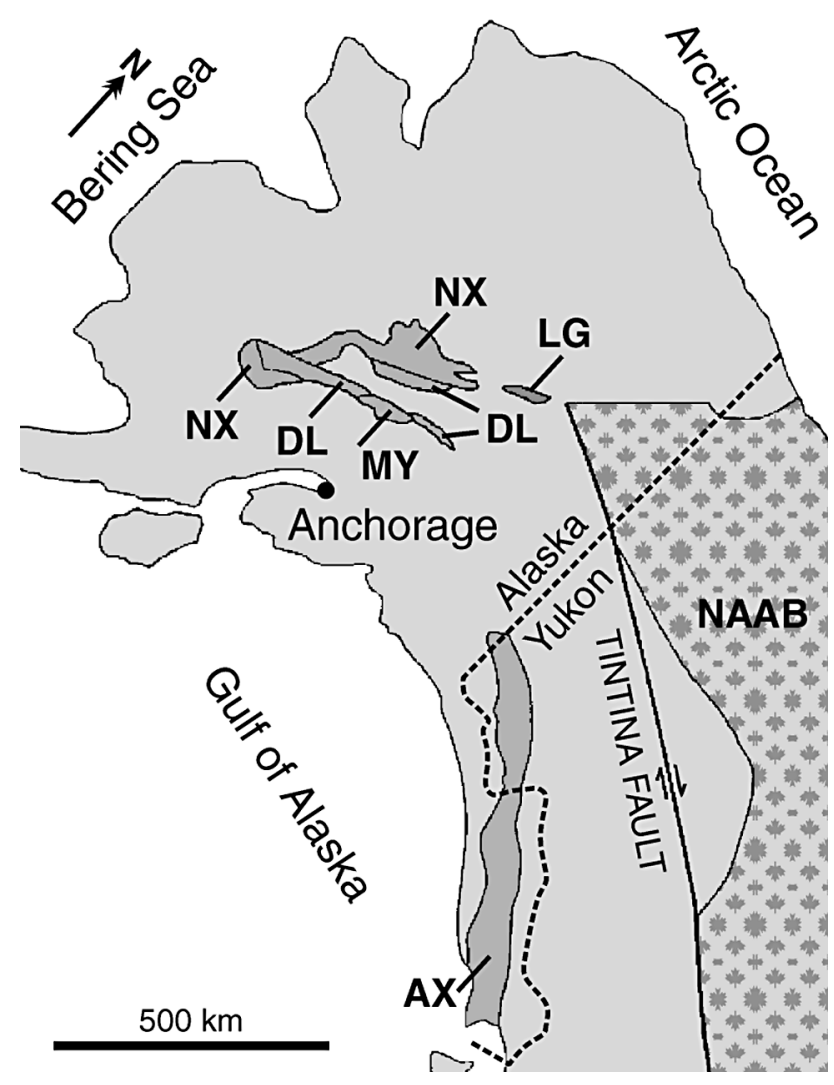

Figure 2. Tectonostratigraphic terranes and component subterranes in Alaska. Abbreviations: AX - Alexander terrane; LG - Livengood terrane, Subterranes of the Farewell terrane: DL - Dillinger; MY - Mystic; NX - Nixon Fork. NAAB - North American autochtonous basement (after Blodgett et al. 2010).

disarticulation suggests a moderately high-energy setting, consistent with our interpretation of moderate transport (but not for great distances) on an inclined shelf to slope transition.

\section{Systematic palaeontology}

Order Atrypida Rzhonsnitskaya, 1960

Suborder Atrypidina Moore, 1952

Superfamily Atrypoidea Gill, 1871

Family Atrypidae Gill, 1871

Subfamily Atrypinae Gill, 1871

\section{Genus Strophatrypa gen. nov.}

Type species. - Strophatrypa skaflestadi gen. et sp. nov. from unnamed upper Silurian strata south of the town of Hoonah, northeast Chichagof Island. The type specimens of Strophatrypa skaflestadi gen. et sp. nov., UAMES 14463-14476, are deposited at the University of Alaska Museum Earth Science Collection, Fairbanks. 
Etymology. - Named to emphasize the strophic interareas, unusual for atrypoid brachiopods.

Diagnosis. - Atrypids with costellae that branch only at concentric growth lines, muscle field in both valves unimpressed, relatively small for the Family, and unique in having very narrow interareas in both valves, extending laterally almost to the maximum width.

Occurrence. - The new genus is known only from the Hoonah quarry locality, and as far as we know is restricted to the Alexander terrane of Southeast Alaska.

Description. - Impunctate, small to medium-size, unequally biconvex shells, with the dorsal valve less convex than the gently convex ventral valve, anterior commissure uniplicate, shells laterally elongate with rounded anterior and lateral margins, semicircular outline, greatest width near midlength, relatively broad, costellate dorsal sulcus and correspondingly broad, costellate ventral fold that have a regular change in slope into the lateral portions of the shells, ornamentation consists of well-marked concentric growth lines crossed by costellae that bifurcate at the first prominent growth line followed by additional bifurcations at more anterior growth lines. Form of deltidial region uncertain.

Ventral valve has two stout laterally broadening hinge teeth with an unimpressed muscle field. The external costellae are well marked interiorly. The dorsal valve has laterally directed, crenulated dental sockets, and a smooth area for diductor attachment, with an unimpressed muscle field, and anterior impressions of the external costellae. Spiralia and jugum unknown.

Comparison. - Lacks the comb-like ctenophoridium of Atrypa sensu strictu. Lacks any trace of dental lamellae, and has a wide, straight hinge line. Lacks the strongly impressed muscle fields present in most members of the Family. Differs from Dehelicteria by possession of prominent, concentric growth lamellae combined with coarser costellae. Has a strophic hinge line in contrast to Omnutakhelia, as well as marked growth lines. Has a strophic hinge line and marked, concentric growth lines in contrast to Gotatrypa, as well as marked fold and sulcus and much lower level of valve convexity.
Discussion. - Although this shell is known from only a single bed at one Alaskan locality its unqiue morpho$\operatorname{logy}$ is worth noting in the hope that similar forms will turn up elsewhere, especially somewhere in Siberia where other taxa restricted to the Silurian of the Alexander terrane are shared. No shells of this type are known from the late Silurian limestones and clastic rocks of Prince of Wales and Heceta Islands, suggesting that the Hoonah occurrence represents a different environment.

\section{Strophatrypa skaflestadi sp. nov.} Figures 3A-Q, 4A-J

Etymology. - Named in honor of Jeff E. Skaflestad of Hoonah, Alaska, who ably guided Blodgett \& Rohr to the Hoonah quarry locality and other geological sites on the northeast part of Chichagof Island.

Diagnosis and description. - Because of monotypy, see that of genus.

Material. - 48 dorsal valves, 36 ventral valves, 4 articulated specimens.

Types. - Holotype, UAMES 14463, Fig. 3A, B; paratype, UAMES14464, Fig. 3C, D; paratype, UAMES 14465, Fig. 3E, F; paratype, UAMES 14466, Fig. 3G, H; paratype, UAMES 14467, Fig. 3I, J; paratype, UAMES 14468, Fig. 3K, L; paratype, UAMES 14469, Fig. 3M, N; paratype, UAMES 14470, Fig. 3O, P; paratype, UAMES 14471, Fig. 3Q; paratype, UAMES 14472, Fig. 4A, B; paratype, UAMES 14473, Fig. 4C, D; paratype, UAMES 14474, Fig. 4E, F; paratype, UAMES 14475, Fig. 4G, H; paratype, UAMES 14476, Fig. 4I, J.

Associated fauna. - The Hoonah late Silurian fauna is a relatively moderate diversity fauna with a dominance of brachiopods to be described subsequently [additional to Strophatrypa there are the following in moderate abundance: Howellella, Mesoleptostrophia, Isorthis (Arcualla), Morinorhynchus, "Atrypa", together with a few valves of a pholidostrophid similar to Eopholidostrophia, several specimens of a gypidulid, a single specimen

Figure 3. Strophatrypa skaflestadi gen. et sp. nov. • A, B - holotype, conjoined valve interiors (impresssion A, rubber replica B) showing the sulcate dorsal valve and the ventral fold; note the laterally directed dental sockets and the strophic hinge line, UAMES $14463, \times 7$. C, D - paratype, dorsal valve interior (impression C, rubber replica D) showing the well developed sulcus, laterally directed, crenulate dental sockets, absence of well impressed muscle field, semicircular outline and impression anteriorly of costellae, UAMES 14464, × $6 . \bullet \mathrm{E}, \mathrm{F}$ - paratype, dorsal valve interior (impression E, rubber replica F), showing the sulcus, laterally directed, crenulate dental sockets, non-impressed muscle area, impression anteriorly of costellae, and semicircular outline, UAMES $14465, \times 6 . \bullet \mathrm{G}, \mathrm{H}$ - paratype, dorsal valve exterior (impression G, rubber replica $\mathrm{H}$ ), showing smooth transition from sulcus to lateral portion of shell, laterally extended, narrow, strophic hingeline, non-lamellose growth lines, and costellae unbranched posteriorly that bifurcate at more 

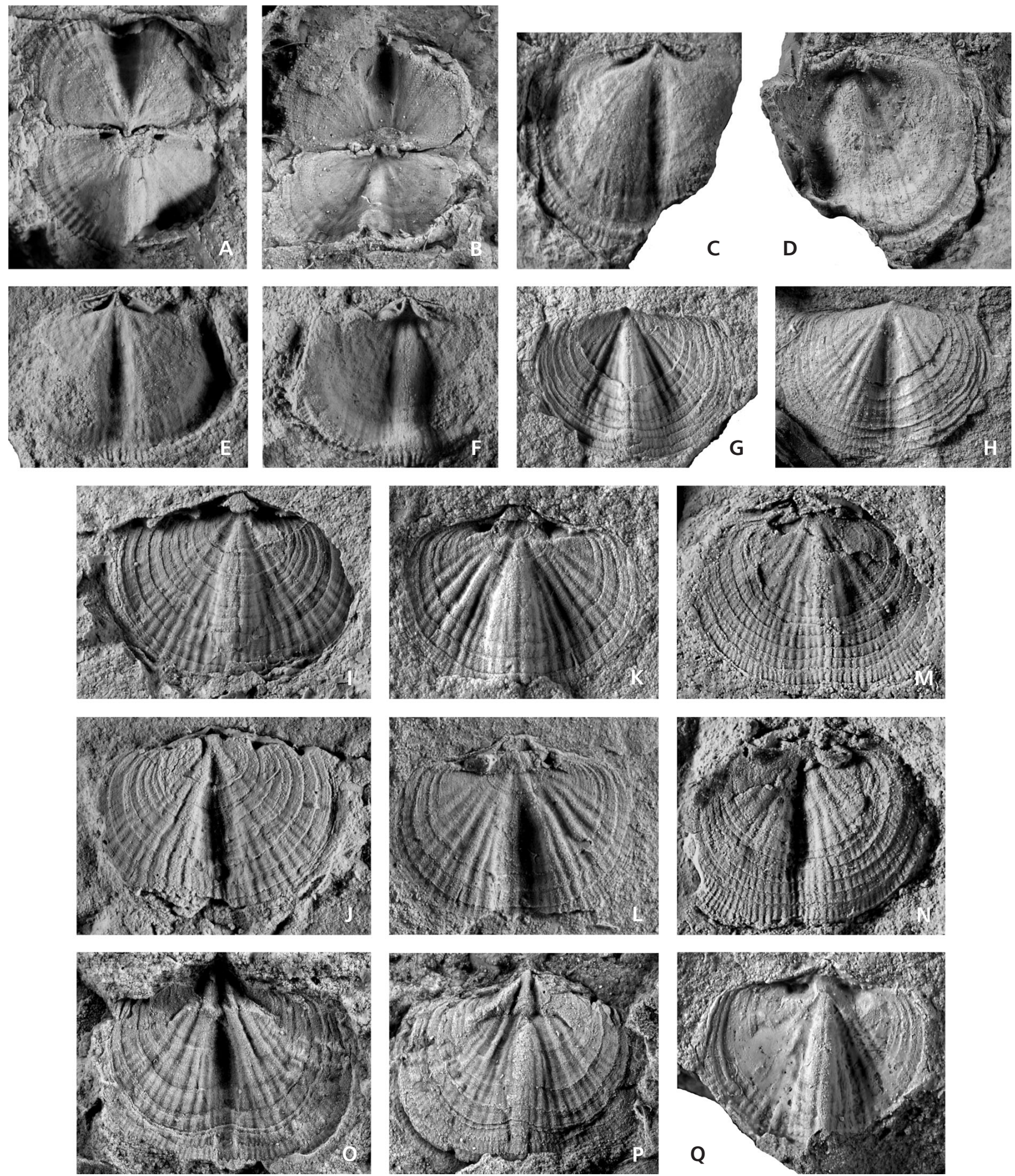

anterior growth lines, UAMES $14466, \times 6 . \bullet \mathrm{I}, \mathrm{J}-$ paratype, dorsal view of conjoined valve interiors (impression I, rubber replica J), showing sulcus and costellae branching at growth lines; note semicircular outline, UAMES $14467, \times 6 . \bullet \mathrm{K}, \mathrm{L}$ - paratype, dorsal view of conjoined valve interiors (impression $\mathrm{K}$, rubber replica L), showing strophic outline, semicircular lateral and anterior margins, UAMES $14468, \times 6 . \bullet \mathrm{M}, \mathrm{N}-$ paratype, dorsal view of conjoined valve interiors (impression $\mathrm{M}$, rubber replica N), showing costellae branching at non-lamellose growth lines, UAMES $14469, \times 6$. $\bullet$, P - paratype, dorsal view of interior (impression $\mathrm{O}$, rubber replica $\mathrm{P}$ ), showing strophic posterior and semicircular outline, with sulcus and costellae branching at growth line, UAMES $14470, \times 6 . \bullet$ Q - paratype, dorsal view of of impression, showing strophic posterior outline, semicircular lateral and anterior outline, and impression of costellae, UAMES $14471, \times 6$. 

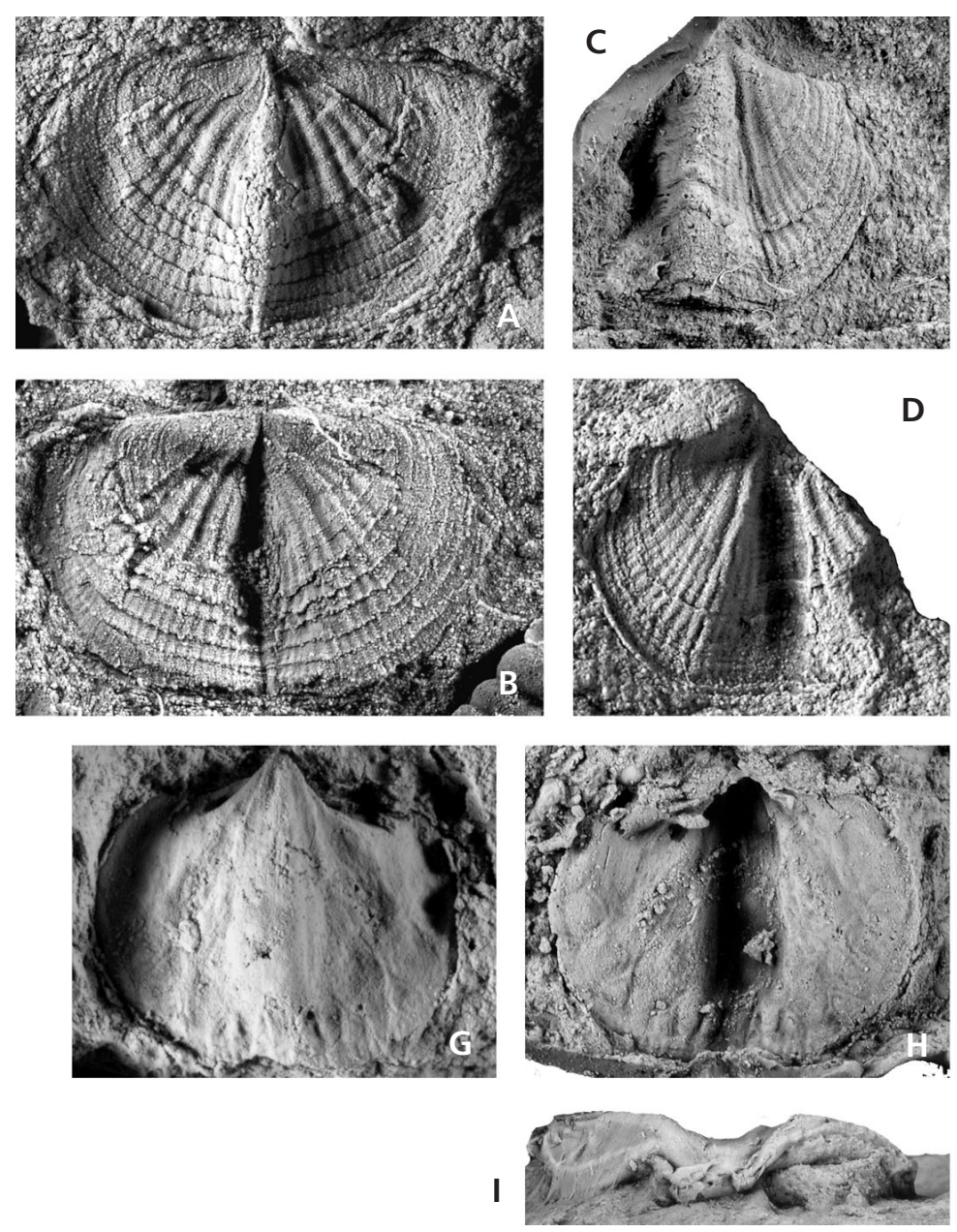
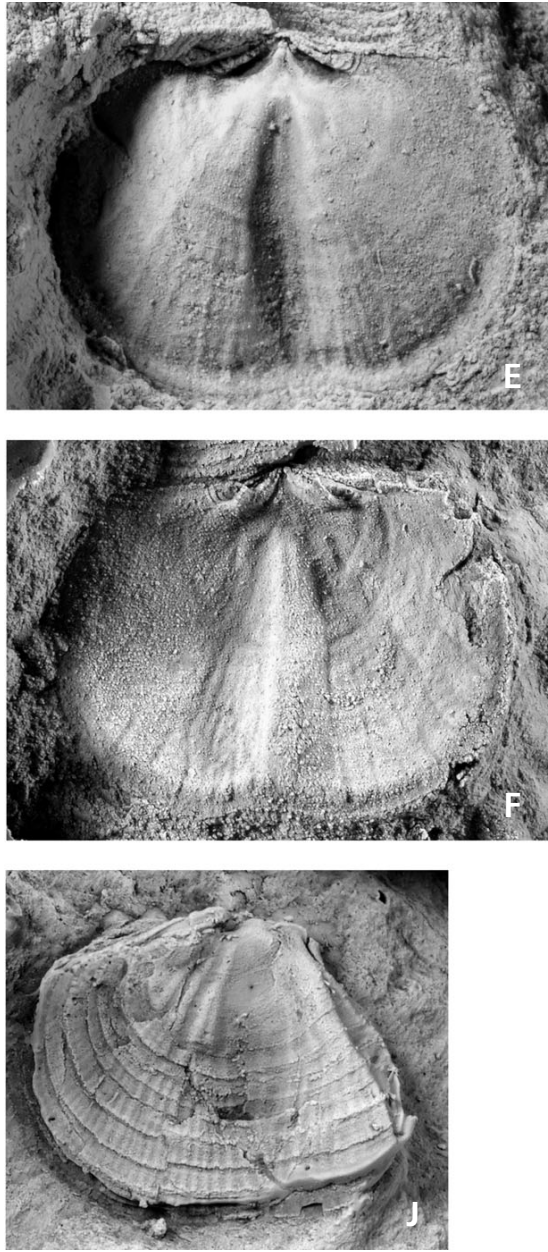

Figure 4. Strophatrypa skaflestadi gen. et sp. nov. $\bullet$ A, B - paratype, dorsal view of exterior (impression A, rubber replica B), showing strophic posterior and semicircular lateral and anterior margins, sulcus, and costellae branching at growth lines, UAMES $14472, \times 6 . \bullet^{\bullet}$, D - paratype, dorsal view of exterior (rubber replica C, impression D), showing sulcus and costellae that branch at growth lines, UAMES $14473, \times 6$. $\bullet$ E, F - paratype, dorsal view of interior (impression E, rubber replica F) showing laterally directed, crenulated dental sockets, sulcus, strophic posterior outline and semicircular lateral and anterior outline, with impression of costellae, UAMES $14474, \times 6 \cdot \bullet \mathrm{G}, \mathrm{H}$ - paratype, impression of ventral interior (impression G, rubber replica H) showing antero-laterally directed hinge teeth, and lack of a well developed muscle impression, UAMES $14475, \times 6$. $\bullet$ I, J - paratype, rubber replica of dorsal valve interior (I - posterior view, $\mathrm{J}$ - dorsal view) showing dental sockets, costellae and semicircular lateral and anterior margins, UAMES $14476, \times 6$.

of a probable Cyrtia, and a single speciment of an unidentified athyroid], a moderate abundance of Bivalvia (Kř́ž et al. 2011), a moderate number of gastropods, rare cephalopods, severals fragments of a favositid, and a few higher land plants fragments under study by Dianne Edwards.

\section{Acknowledgements}

We are deeply indebted to Jeff E. Skaflestad of Hoonah, Alaska, who proved to be an excellent guide during our field work on Chichagof Island and led us to the quarry where the brachiopod described here was discovered. We wish to thank Valeryi V. Baranov (Yakutsk, Russia) for his helpful review of this paper.

\section{References}

BerG, H.C., Jones, D.L. \& Richter, D.H. 1972. Gravina-Nutzotin Belt; tectonic significance of an upper Mesozoic sedimentary and volcanic sequence in southern and southeastern Alaska. U.S. Geological Survey Professional Paper 800-D, D1-D24.

Blodgett, R.B. \& Boucot, A.J. 2009. The Alexander Terrane a displaced fragment of Northeast Siberia? Evidence from Silurian brachiopods and Silurian-Lower Devonian stratigraphy [abstract]. Geological Society of America Abstracts with Programs 41(7), 302.

Blodgett, R.B., Boucot, A.J., Rohr, D.M. \& Pedder, A.E.H. 2010. The Alexander terrane of Alaska - a displaced fragment of Northeast Russia? Evidence from Silurian-Middle Devonian megafossils and stratigraphy. Memoirs of the Association of Australasian Palaeontologists 39, 323-339. 
Blodgett, R.B., Rohr, D.M. \& Boucot, A.J. 2002. Paleozoic links among some Alaskan accreted terranes and Siberia based on megafossils, 273-290. In Miller, E.L., Grantz, A. \& KLEMPERER, S.L. (eds) Tectonic evolution of the Bering ShelfChukchi Sea-Arctic margin and adjacent landmasses. Geological Society of America Special Paper 360.

BlodgetT, R.B., Rohr, D.M., Karl, S.M. \& Baichtal, J.F. 2003. Early Middle Devonian (Eifelian) gastropods from the Wadleigh Limestone in the Alexander terrane of southeastern Alaska demonstrate biogeographic affinities with central Alaskan terranes (Farewell and Livengood) and Eurasia, 105-115. In GALLOWAY, J.P. (ed.) Studies in Alaska by the U.S. Geological Survey, 2001. U.S. Geological Survey Professional Paper 1678.

Clough, J.G. \& Blodgett, R.B. 1988. Silurian-Devonian algal reef mound complex of southwest Alaska, 246-250. In GELDSETZER, H. \& JAMES, N. P. (eds) Reefs, Canadian and adjacent areas. Canadian Society of Petroleum Geologists Memoir 13.

FLÜGEL, E. 2004. Microfacies of carbonate rocks; analysis, interpretation and application. 976 pp. Springer, Berlin.

GILL, T. 1871. Arrangement of the families of mollusks prepared for the Smithsonian Institution. Smithsonian Miscellaneous Collections 227, 1-49.

Jones, D.L., Irwin, W.P. \& Ovenshine, A.T. 1972. Southeast Alaska; a displaced continental fragment? U.S. Geological Survey Professional Paper 800-B, B211-B217.

KARL, S.M. 1999. Preliminary geologic map of northeast Chichagof Island, Alaska. U.S. Geological Survey Open-File Report 96-53, 12 pp., 1 map sheet, scale 1:63,360.

KIRK, E. 1922. Brooksina, a new pentameroid genus from the Upper Silurian of southeastern Alaska. Proceedings of the United States National Museum 60(19), 1-8. DOI 10.5479/si.00963801.60-2414.1

KIRK, E. 1925. Harpidium, a new pentameroid brachiopod genus from southeastern Alaska. Proceedings of the United States National Museum 66(32), 1-7.

DOI 10.5479/si.00963801.66-2569.1

KIRK, E. 1926. Cymbidium, a new genus of Silurian pentameroid brachiopods from Alaska. Proceedings of the United States National Museum 69(23), 1-5.

DOI 10.5479/si.00963801.69-2649.1

KIRK, E. 1927a. Pycnodesma, a new molluscan genus from the Silurian of Alaska. Proceedings of the United States National Museum 71(20), 1-9. DOI 10.5479/si.00963801.71-2692.1

KIRK, E. 1927b. Pycinodesma, a new name for Pycnodesma Kirk not Schrammen. Journal of the Washington Academy of Sciences 17, 543.

KiRK, E. \& AMSDEN, T.W. 1952. Upper Silurian brachiopods from southeastern Alaska. U.S. Geological Survey Professional Paper 233(C), 53-66.

Křiž, J., BlodgetT, R.B. \& Rohr, D.M. 2011. Silurian Bivalvia from Chichagof Island, Southeast Alaska (Alexander terrane). Bulletin of Geosciences 86(2), 241-258.

DOI 10.3140/bull.geosci.1277

Lathram, E.H., Loney, R.A. \& Condon, W.H. 1958. Progress map of the geology of the Juneau quadrangle, Alaska. U.S. Geological Survey Miscellaneous Investigations 276, 1 sheet, scale 1:250,000.
Lathram, E.H., Loney, R.A., Condon, W.H. \& BerG, H.C. 1959. Progress map of the geology of the Juneau quadrangle, Alaska. U.S. Geological Survey Miscellaneous Investigations Map I-303, 1 sheet, scale: 1:250,000.

Loney, R.A., Berg, H.C., Pomeroy, J.S. \& Brew, D.A. 1963a. Reconnaissance geologic map of Chichagof Island and northwestern Baranof Island, Alaska. U.S. Geological Survey Miscellaneous Geologic Investigations Map I-388, 7 pp., 1 sheet, scale 1:250,000.

Loney, R.A., Condon, W.H. \& Dutro, J.T., JR. 1963b. Geology of the Freshwater Bay area, Chicagof Island, Alaska. U.S. Geological Survey Bulletin 1108-C, C1-C54, 2 sheets, scale $1: 63,360$.

Moore, R.C. 1952. Brachiopoda, 197-267. In Moore, R.C., LALICKER, C.G. \& Fischer, A.G. (eds) Invertebrate Fossils. McGraw-Hill, New York.

PedDER, A.E.H. 2006. Zoogeographic data from studies of Paleozoic corals of the Alexander terrane, southeastern Alaska and British Columbia, 29-57. In HaGgart, J.W., Enkin, R.J. \& Monger, J.W.H. (eds) Paleogeography of the North American Cordillera: Evidence for and against large-scale displacements. Geological Association of Canada, Special Paper 46.

Rigby, J.K., Nitecki, M.H., Soja, C.M. \& Blodgett, R.B. 1994. Silurian aphrosalpingid sphinctozoans from Alaska and Russia. Acta Palaeontologica Polonica 39, 341-391.

Rohr, D.M. \& BlodgetT, R.B. 2003. Kirkospira, a new Silurian gastropod from Glacier Bay, Southeastern Alaska, 117-125. In Galloway, J.P. (ed.) Studies by the U.S. Geological Survey in Alaska, 2001. U.S. Geological Survey Professional Paper 1678.

Rohr, D.M. \& BlodgetT, R.B. 2008. Silurian Gastropoda from the Alexander terrane, Southeast Alaska, 51-61. In BLodgetT, R.B. \& STANLEY, G.D. (eds) The terrane puzzle: New perspectives on paleontology and stratigraphy from the North American Cordillera. Geological Society of America Special Paper 442.

Rohr, D.M., Blodgett, R.B., Boucot, A.J. \& Skaflestad, J. 2011. Upper Silurian facies and fauna of northeast Chichagof Island, Southeast Alaska [abstract]. 2011 Western Region Meeting SPE Pacific Section, AAPG 6-14 May 2011. Program with Abstracts, 82.

Rohr, D.M, Blodgett, R.B. \& FrÝdA, J. 2003. New Silurian murchisoniid gastropods from Alaska and a review of the genus Coelocaulus, 87-93. In Clautice, K.H. \& Davis, P.K. (eds) Short Notes on Alaska Geology, 2001. Alaska Division of Geological \& Geophysical Surveys Professional Report 120.

Rohr, D.M., BlodgetT, R.B. \& FRÝDA, J. 2008. Silurian Gastropoda from southeastern and west-central Alaska. Journal of Paleontology 82, 604-611. DOI 10.1666/07-006.1

Rzhonsnitskaya, M.A. 1960. Otryad Atrypida, 257-264. In SARYChEva, T.G. (ed.) Mshanki, Brakhiopody. Osnovy Paleontologii, Volume 7. Akademiya Nauk SSSR, Moskva.

SAVAGE, N.M. 1989. The occurrence of the brachiopods Nanukidium and Atrypoidea in the Late Silurian of southeastern Alaska, Alexander terrane. Journal of Paleontology 63, 530-533. 